\title{
Research on the Modes of Undertaking Industry Transfer: Based on the Beijing-Tianjin-Hebei Regional Industrial Isomorphism
}

\author{
Jingmin Wang ${ }^{1}$, \\ North China Electric Power University \\ NCEPU \\ Baoding, China \\ www.zhlw140430@163.com
}

\author{
Hao Zhang ${ }^{2}$ \\ North China Electric Power University \\ NCEPU \\ Baoding, China \\ www.zhlw140430@163.com
}

\begin{abstract}
Industrial collaborative development, as an important joint, lays the foundation for Beijing-Tianjin-Hebei collaboration development. By analysis of the industrial isomorphism coefficient, location quotient and industrial gradient coefficient, it is concluded that the industrial structure of Beijing-Tianjin-Hebei region shares great similarities, which may delay the procession of industrial transfer. In order to address the issue, the industrial gardens models including the characteristic industrial garden mode," Industrial chain garden" mode, recycling industrial garden mode, "Professional town" mode, "Cooperative project garden" mode are proposed, providing policy enlightenments for the acceleration of Beijing-Tianjin-Hebei collaboration development.
\end{abstract}

Keywords-Beijing-Tianjin-Hebei Region; industrial isomorphism; industrial gradient coefficient; industrial cluster; garden models

\section{INTRODUCTION}

Government work report promoted strategy of Beijing-Tianjin-Hebei collaboration development for country's top development strategy in 2014. The 13th Five-Year Plan indicated that Beijing-Tianjin-Hebei collaboration development would be essential part of development. Beijing as the core of it is suffering from "urban disease" population growth, traffic congestion and air pollution problems in recent years. In order to solve the economic, Industry transfer has become the important means to solve the problem. It has important practical significance in solving Beijing "urban disease", easing the capital's function, promoting industrial transfer policy formulation and Beijing-Tianjin-Hebei collaboration development. With the further the coordinated development of Beijing-Tianjin-Hebei, regional cooperation began to substantive stage. However, due to the factors, including resources endowment and local government game, influence on the development of the region, the phenomenon of industrial isomorphism has become a striking feature in the development of Beijing-Tianjin-Hebei region. The industrial isomorphism is that the regional industrial structure, especially the

The author would like to express his acknowledgements to the Beijing Social and Scientific Fund for the financial support under 15JGB050. industrial structure, presents a common trend in the process of economic development. The area of different resources endowment forms the same or similar industrial structure pattern. It is generally believed that excessive industrial isomorphism will affect the efficiency of resource allocation, and thus slow the efficiency of regional cooperation and development in the whole area.

\section{MEASUREMENT AND ANALYSIS OF THE BEIJING-TIANJIN-HEBEI INDUSTRY ISOMORPHISM}

\section{A. Regional economic development}

Beijing-Tianjin-Hebei existed the obvious industrial gradient difference by means of the comparison of industrial structure. Beijing and Tianjin are in high gradient, Hebei is low gradient. The second industry output value of Tianjin and Hebei accounted for about 50\% of its GDP in 2014 .That Tianjin is a typical industrial cit. Hebei province also has a higher level of industrialization, but the proportion of primary industry is significantly higher than the Beijing and Tianjin, reducing the seating arrangement of its industrialization. Although Beijing second industry is only $21.4 \%$ in GDP, tertiary industry accounted for $77.9 \%$, $28.6 \%$ higher than in Tianjin, $40.6 \%$ higher than in Hebei province. Beijing has entered a stage of post-industrial, Hebei and Tianjin is still in the industrial stage marked by "two, three, and one".

TABLE I. BEIJING-TIANJIN-HEBEI PROPORTION OF THREE INDUSTRIES IN 2014

\begin{tabular}{|c|c|c|c|}
\hline & The first industry & The second industry & The third industry \\
\hline Beijing & 0.7 & 21.4 & 77.9 \\
\hline Tianjin & 1.3 & 49.4 & 49.3 \\
\hline Hebei & 11.7 & 51 & 37.3 \\
\hline
\end{tabular}

B. Regional industrial structure convergence and similarity

Considering the data availability the data is the Beijing-Tianjin-Hebei region industry main business income in 2014. Industrial structure similarity coefficient 
which is recommended by the United Nations industrial development organization international industrial research center is recommend as index judging the degree of industrial isomorphism. Computation formula is as follows:

$$
S_{i j}=\sum_{k=1}^{n}\left(x_{i k} X_{j k}\right) / \sqrt{\sum_{k=1}^{n} x_{i k}^{2} \sum_{k=1}^{n} x_{j k}^{2}}
$$

$S_{i j}$ is the structure similarity coefficient, $i$ and $j$ are two regions, $X_{i k}$ is the region $\mathrm{k}$ accounted for the proportion of the whole industry in industry $i, x_{j k}$ is the region $\mathrm{k}$ accounted for the proportion of the whole industry in industry $\mathrm{j}$. If $S_{i j}$ is bigger, explaining that the degree of industrial isomorphism between the two places is greater. From the dynamic point, if the similarity coefficient tends to rise, the industrial structure tends to be the same. It is generally believed that similarity coefficient is greater than 0.5 , which said that industry convergence is larger. The industrial structure adjustment should be performed.

TABLE II. THE SIMILAR COEFFICIENT OF INDUSTRIAL STRUCTURE IN BEIJING-TIANJIN-HEBEI REGION

\begin{tabular}{|c|c|c|c|}
\hline Year & Beijing-Tianjin & Beijing-Hebei & Tianjin-Hebei \\
\hline 2014 & 0.87 & 0.77 & 0.97 \\
\hline 2009 & 0.74 & 0.41 & 0.83 \\
\hline
\end{tabular}

Because of the top ten industries and the similarity coefficient between each other in Beijing-Tianjin-Hebei region, it said that Beijing-Tianjin and Tianjin-Hebei exists serious industrial convergence, the tendency of competition is high. The similarity coefficient of Beijing-Hebei is low, it said that industrial difference is obvious and the tendency of collaboration is high. Through the comparison structure similarity coefficient in 2014 and 2009 found that the result is improved, Beijing Tianjin Hebei industrial structure develop in the same way. Especially the similarity coefficients are obvious improved in Beijing - Hebei and Tianjin- Hebei, industrial structure of Hebei is optimized and upgraded.

\section{Regional structure specialization}

The industrial structure convergence or divergence is not the sufficient condition of malignant competitions existence or not. Industrial structure isomorphism orientated by market has the certain inherent inevitability and rationality. Computation formula is as follows:

$$
L Q_{i j}=\frac{L_{i j} / \sum_{j} L_{i j}}{\sum_{j} L_{i j} / \sum_{i} \sum_{j} L_{i j}}
$$

TABLE III. THE TOP TEN INDUSTRY OF BEIJING LOCATION QUOTIENT IN 2014

\begin{tabular}{|c|l|c|}
\hline \multirow{2}{*}{$\begin{array}{c}\text { The serial } \\
\text { number }\end{array}$} & Name of the industry & Beijing \\
\cline { 2 - 3 } & location quotient \\
\hline 1 & Mining auxiliary activities & 4.74 \\
\hline 2 & $\begin{array}{l}\text { Product and supplying Electricity, heat } \\
\text { industry }\end{array}$ & 3.94 \\
\hline 3 & Gas production and supply industry & 3.19 \\
\hline 4 & Car manufacturing & 3.06 \\
\hline 5 & Water production and supply industry & 2.56 \\
\hline 6 & $\begin{array}{l}\text { Metal products, machinery and equipment } \\
\text { repair industry }\end{array}$ & 2.53 \\
\hline 7 & $\begin{array}{l}\text { Mining and Processing Ferrous metal } \\
\text { industry }\end{array}$ & 2.21 \\
\hline 8 & Instrument manufacturing industry & 2.02 \\
\hline 9 & $\begin{array}{l}\text { Computer, communications, and other } \\
\text { electronic devices }\end{array}$ & 1.83 \\
\hline 10 & Pharmaceutical manufacturing industry & 1.61 \\
\hline
\end{tabular}

TABLE IV. THE TOP TEN INDUSTRY OF BEIJING LOCATION QUOTIENT IN 2014

\begin{tabular}{|c|l|c|}
\hline \multirow{2}{*}{$\begin{array}{c}\text { The serial } \\
\text { number }\end{array}$} & \multicolumn{2}{|c|}{ Tianjin } \\
\cline { 2 - 3 } & Name of the industry & location quotient \\
\hline 1 & Oil and gas industry & 4.03 \\
\hline 2 & $\begin{array}{l}\text { Black metal smelting and rolling processing } \\
\text { industry }\end{array}$ & 2.57 \\
\hline 3 & $\begin{array}{l}\text { Comprehensive utilization of waste } \\
\text { resources }\end{array}$ & 2.43 \\
\hline 4 & Food manufacturing industry & 2.41 \\
\hline 5 & Coal mining and washing industry & 2.25 \\
\hline 6 & Railway, shipbuilding, aerospace and other & 2.01 \\
\hline 7 & Mining auxiliary activities & 1.81 \\
\hline 8 & Other manufacturing & 1.57 \\
\hline 9 & Fabricated metal products & 1.40 \\
\hline 10 & $\begin{array}{l}\text { Computer, communications, and other } \\
\text { electronic devices }\end{array}$ & 1.32 \\
\hline
\end{tabular}

TABLE V. THE TOP TEN INDUSTRY OF BEIJING LOCATION QUOTIENT IN 2014

\begin{tabular}{|c|l|c|}
\hline \multirow{2}{*}{$\begin{array}{c}\text { The serial } \\
\text { number }\end{array}$} & \multicolumn{2}{|c|}{ Hebei } \\
\cline { 2 - 3 } & Name of the industry & 5.84 \\
\hline 1 & $\begin{array}{l}\text { Mining and Processing Ferrous metal } \\
\text { industry }\end{array}$ & 3.51 \\
\hline 2 & $\begin{array}{l}\text { Black metal smelting and rolling processing } \\
\text { industry }\end{array}$ & 2.15 \\
\hline 3 & $\begin{array}{l}\text { Leather, fur, feather and its products } \\
\text { manufacturing }\end{array}$ & 1.71 \\
\hline 4 & Fabricated metal products industry & 1.43 \\
\hline 5 & Coal mining and washing industry & 1.20 \\
\hline 6 & $\begin{array}{l}\text { Product and supplying Electricity, heat } \\
\text { industry }\end{array}$ & 1.09 \\
\hline 7 & $\begin{array}{l}\text { Duplicating industry printing and recording } \\
\text { media industry }\end{array}$ & 1.09 \\
\hline 8 & Food manufacturing industry & 1.08 \\
\hline 9 & $\begin{array}{l}\text { Oil processing and coking and nuclear fuel } \\
\text { processing industry }\end{array}$ & 1.06 \\
\hline 10 & Textile industry & \\
\hline
\end{tabular}


Though the comparison of the Beijing-Tianjin-Hebei industry location quotient, we said that the advantage of industry in Beijing focus on the service life, technology, capital intensive modern manufacturing; The advantage of Tianjin industry concentrated in the equipment manufacturing industry and modern manufacturing; The advantage of Hebei industry mainly resource processing, labor-intensive industries.

\section{Prepare Your Paper Before Styling}

In recent years, a large number of chemical gardens with the cluster development are built throughout the Beijing-Tianjin-Hebei Region. Therefore, the carrier function of garden plays an important role in industrial cluster space transfer, and different garden positioning and development pattern also presents different cluster transfer characteristics and modes. There are five modes which gardens serve as the carrier of undertaking industrial transfer.

\section{A. The characteristic industrial garden mode}

The characteristic industrial garden (CIG), a type of industry groups, is often conceived as the result of economy development at certain stage that takes advantage of local industries, enterprises, products, raw materials market and professional marketing teams which have a certain scale. CIG can also be described as a cluster industrial garden that, arguably, relies on industry, whilst using real estate as a carrier. It is apparent, therefore, that the CIG is comprehensive regional characterized economy.

\section{B. "Industrial chain garden" mode}

In order to promote the extension of industrial chain, some areas of lower economic development have taken a package of strategies to transfer industry. The transfer industry mode is also called chain industrial park mode, which associates enterprises to an industrial garden. The characteristics of this model are: This mode focuses on the quality of attracting investment, rather than quantity of it, the better for all market participants. The emphasis of attracting investment is to seeking talented enterprises to add more derivatives.

\section{Recycling industrial garden mode,}

The circular economy industrial park is a new type of industrial organization form whose design relies on the industrial ecology and circular economy theory. It designs the logistics and energy flow in industrial park by simulating the natural ecosystem; matter and energy in park are grounds interaction in geographical spatial agglomeration of enterprises.

\section{D. "Professional town" mode}

"Professional town" refers to the industrial system of a rural area including the coordinated development of leading industry, secondary industry and service industry. The meaning of "professional town" is embodied in two aspects: one is the industrial structure, on the basis of the leading industry leading industry, secondary industry and service industry coordinated development of regional industry system.

\section{E. "Cooperative project garden" mode}

The pattern to build garden with cooperation is based on the their own characteristics of industrial transfer and undertake cooperation, the advantages and disadvantages in both development direction in the selection, planning, formulation, capital investment and operation management to build and share the benefits according to the cooperation agreement. From the main body on the park to build the cooperation, there are mainly five kinds of cooperation mode: garden and park; park and enterprises; park and the government; enterprise and the government.

\section{CONCLUSIONS}

This paper suggests the phenomenon of industry isomorphism in Beijing-Tianjin-Hebei region is serious, which leads to aggravate regional competition and prejudice industrial transfer. The garden as the carrier of the transfer of industrial cluster is a very good way to promote industrial transfer. Though arranging the research achievement, five garden modes undertaking industrial transfer are brought forward. It has important practical significance in solving Beijing "urban disease", easing the capital's function, promoting industrial transfer policy formulation and Beijing-Tianjin-Hebei collaboration development.

\section{REFERENCES}

[1] Zhang Kai, "Compatible development of industry in Beijing-Tianjin-Hebei region", Wuhan: Huazhong University of Science and Technology, May 2007.

[2] D. He, F. Jin and J. Cai, "Simulation and prediction of urban spatial growth in the past 20 years in Jing - Jin - Lang area", Economic Geography, vol. 31, pp. 7-13, 2011.

[3] Wang Sujun and QuYi, "Port Group coordinated development and relations analysis of port and hinterland in Beijing-Tianjin-Hebei region", Economic and management, vol. 22, pp. 57-61, May 2009.

[4] Z. X. Huang, "Problems and Countermeasures of Jing-Jin-Ji Urban Agglomeration", China Economic \& Trade Herald, vol. 11, pp. 47-49, Nov. 2008.

[5] Y. Tanglin, "Beijing-Tianjin-Hebei regional industrial upgrading and integration study during the period of twelfth five-year [J]", Research on Development, no. 1, pp. 23-26, 2011

[6] Lin Li, "Analysis on the Obstacles of Middle and Western Regions' Undertaking Industry Transfer from Eastern Regions", Journal of the Southeast University for Nationalities (Humanity and Social Edition), pp. 156-160, 2010.

[7] Long-bin He, On Hot Accepting Domestic Industrial Transfer in Western Regions Modern Economic Review, pp. 24-27, 2010. 